\title{
Relationship between spirituality and suicidal ideations among patients with major depressive disorder
}

\author{
Souzan Abd El-Menem Abd El-Ghafar Harfush, PhD \\ Psychiatric and Mental Health Nursing Department, Faculty of Nursing, \\ Tanta University, Tanta, Egypt
}

\section{INTRODUCTION}

Suicide still constitutes to be a critical and risky issue requiring preventive strategies. There is evidence to suggest that spirituality is vital to the process of discovering meaning in life and plays an important role in dealing with suicidal desire

\section{METODOLOGY}

A descriptive correlational design was utilized in the current study. A purposive sample of 181 patients with major depressive disorder was recruited. Setting: The study was conducted at inpatient psychiatric department of Tanta University and Neurology, Psychiatry, and NeuroSurgery Center. Tools: Four tools were used to collect data; socio-demographic and clinical characteristics structured interview schedule, Beck Depression Inventory (1), Daily Spiritual Experience Scale(2), and Scale for Suicide Ideation (3)

\section{OBJECTIVES}

The objective of this study was to investigate the relationship between spirituality and suicidal ideations among patients with major depressive disorder.

\section{RESULTS}

\begin{tabular}{|c|c|c|c|}
\hline $\begin{array}{l}\text { Distribution of studied subjects in } \\
\text { relation to total score of suicide, }\end{array}$ & Variable & $\begin{array}{c}\text { Depression } \\
\mathbf{r} \\
\mathbf{p}\end{array}$ & $\begin{array}{c}\text { Spirituality } \\
\mathbf{r} \\
\mathbf{p}\end{array}$ \\
\hline depression and spirituality: & Depression & - & $\begin{array}{l}-0.259 \\
001 *\end{array}$ \\
\hline that, $44.2 \%$ of the studied patients & Spirituality & - & - \\
\hline $\begin{array}{l}\text { had moderate score of suicide } \\
\text { compared to } 14.4 \% \text { only who had }\end{array}$ & $\begin{array}{l}\text { Total suicide } \\
\text { score }\end{array}$ & $\begin{array}{r}0.719 \\
.001^{*}\end{array}$ & $\begin{array}{l}-0.003 \\
.968\end{array}$ \\
\hline $\begin{array}{l}\text { high score of suicide with a mean } \\
\text { score of } 40.56 \pm 15.54 \text {. While, nearly } \\
\text { two thirds of patients ( } 64.8 \% \text { ) had } \\
\text { fair score of spirituality with a mean } \\
\text { score of } 60.56 \text { 6.93. about half of }\end{array}$ & $\begin{array}{l}\text { Suicide } \\
\text { subscales } \\
\text { Active } \\
\text { suicide } \\
\text { desire }\end{array}$ & $\begin{array}{l}0.636 \\
001^{*}\end{array}$ & $\begin{array}{l}-0.184 \\
013^{*}\end{array}$ \\
\hline $\begin{array}{l}\text { the patients ( } 49.5 \% \text { ) have moderate } \\
\text { score of depression and the rest of }\end{array}$ & Preparation & $\begin{array}{l}0.715 \\
001^{*}\end{array}$ & $\begin{array}{l}-0.118 \\
.115\end{array}$ \\
\hline $\begin{array}{l}\text { patients had either severe or mild } \\
\text { depression }(28.1 \% \text { and } 22.1 \% \\
\text { respectively) with a mean score of }\end{array}$ & $\begin{array}{l}\text { Passive } \\
\text { suicide } \\
\text { desire }\end{array}$ & $\begin{array}{l}0.484 \\
001^{*}\end{array}$ & $\begin{array}{l}0.004 \\
.958\end{array}$ \\
\hline
\end{tabular}

\section{CONCLUSION}

correlation between suicide, spirituality and depression.

It was noted that, there is a statistical significant negative correlation between depression and spirituality. This means increasing spiritual involvement is associated with decreasing level of depression ( $r=-0.259$, $p$ $\left.=.001^{*}\right)$. Also, there is a statistical significant positive correlation between depression and total score of suicide $(r=$ $\left.0.719, p=.001^{*}\right)$. On the other hand ,there is a correlation between total suicide score and spirituality but not proved to be statistically significant $(r=-$ 0.003, $p=.968$ )
Based on the results of the present study, it can be concluded that higher levels of spirituality may help buffer risk of active suicide desire and promote protective effect against depression.

1- Beck AT, Steer RA, Brown GK. Psychometric properties of the beck depression inventory: twenty-five years of evaluation. Clinical Psychology Review. 1998; 8(1): 77100.

2-Lace J, Handal P. Psychometric properties of the daily spiritual experiences scale: support for a two-factor solution, concurrent validity, and its relationship with clinical psychological distress in University students. Religions Journal. 2017; 8(123): 1-17.

3-Beck A, Kovacs M, Weissman A. Assessment of suicidal intention: the Scale for Suicide Ideation. Journal of Consulting and Clinical Psychology. $1979 ; 47(2): 343-52$.

\section{REFERENCES}

